\title{
Feedback between Psychological Science and Policy in the Context of Same-Sex Couples
}

\author{
Adam W. Fingerhut ${ }^{1}$ and David M. Frost ${ }^{2}$ \\ ${ }^{1}$ Department of Psychology, Loyola Marymount University \\ ${ }^{2}$ Department of Social Science, University College London
}

\begin{abstract}
Author Note:
Correspondence concerning this article should be addressed to Adam W. Fingerhut, Department of Psychology, Loyola Marymount University, University Hall, Suite 4700, Los Angeles CA 90045-2659. Email: adam.fingerhut@LMU.edu
\end{abstract}




\begin{abstract}
Psychological science informed recent policy changes granting increased rights for same-sex couples. Understanding that the link between science and policy goes both ways, how should policy inform the next generation of research concerning same-sex couples and sexual minority individuals? This paper presents ways that psychological research influenced marriage policy and then puts forth suggestions for future research for the attention of scholars, funders, and policy makers. These include examinations of minority stress in the age of marriage equality; new stressors for same-sex couples including legal divorce; relationship expectations and experiences for emerging adults; and the potential impact of marriage equality for mixed-sex couples including a further challenge to strict gender roles in marriage. The paper ends by acknowledging the need for continued application of research to emerging policy questions affecting same-sex couples and sexual minority individuals.

Keywords: same-sex couples; marriage equality; policy; romantic relationships; minority stress
\end{abstract}

\title{
Bulleted highlights
}

1. Social scientific data and policies can inform each other, given increased rights for samesex couples.

2. Critically, marriage equality may or may not decrease minority stressors such as discrimination and increase perceived equality among sexual minority individuals.

3. New stressors may emerge with legally recognized marriage for same-sex couples, e.g., divorce within a heteronormative system that often relies on stereotyped gender roles. 
4. Young adults coming of age and perhaps coming out in a time of greater rights may have distinct expectations for and experiences with romantic relationships, compared with older generations of sexual minority individuals.

5. Same-sex couples may assimilate pre-existing norms of marriage or change them for everyone; gender roles within marriage (e.g., couple division of labor) could also change.

6. The suggestions presented apply to scholars and funders interested in sexual minority populations and the aftermath of marriage equality. They also apply more broadly to: scholars interested generally in policy and structural stigma; policy makers invested in examining the consequences of changes to marriage policy; and scholars, funders, and policy makers dedicated to achieving inclusiveness through policies grounded in empirical data.

\section{0-character tweet}

Given marriage equality for same-sex couples, research and policy must attend to: experiences of minority stress and inclusion; the creation of new stressors including divorce; the relationship expectations of young adults; and possible impacts for marriage more broadly. 


\section{Feedback between Psychological Science and Policy in the Context of Same-Sex Couples}

In the current era, social scientific data have informed policies affecting same-sex couples. Understanding the link between science and policy as symbiotic raises the question of how these policy reforms should inform the next generation of research concerning same-sex couples and sexual minority individuals. This paper offers ways for researchers and sponsors of research to shape a new agenda for moving forward.

\section{Social Science Influences on Policy}

Legal changes in the new millennium have increased protection and equality for sexual minority individuals and same-sex couples. Just as Kenneth and Mamie Clark’s doll study informed the U. S. Supreme Court's decision in Brown v. Board of Education and thus national policy regarding school segregation (Heise, 2005), social scientific data have influenced policies affecting same-sex couples. Nowhere has this been clearer than in access to marriage.

Even before the federal cases, the American Psychological Association (APA) and other leading social science bodies brought data to a brief for In re Marriage Cases (2008), a California Supreme Court Case examining the legitimacy of California's Proposition 22 that created a family code law limiting California marriages to one man and one woman. The brief laid out comprehensive data to argue that excluding same-sex couples from marriage is ungrounded and damaging. Data cemented the inextricable link between same-sex sexual orientation and the gender of one's partner. Data also demonstrated that same-sex couples form stable, committed relationships that are often indistinguishable from mixed-sex couples on markers of relational health and quality. Data further showed marriage as an institution that provides social and psychological benefits and that exclusion from the institution constitutes 
discrimination. In overturning Proposition 22, the California State Supreme Court cited only this brief out of all 45 submitted.

In the federal cases addressing marriage equality, psychological data also appeared. The United States District Court case Perry v. Schwarzenegger (2010) concerned the constitutionality of California's Proposition 8, a state constitutional amendment banning marriage for same-sex couples. Judge Vaughn Walker, who presided over the case, invited oral testimony, much provided by leading psychologists, including Anne Peplau, Gregory Herek, Ilan Meyer, and Michael Lamb. Again, as with the APA briefs, these experts presented data ranging from the nature of sexual orientation to the effects of stigma to the well-being of children raised by sexual minority individuals and same-sex couples. In his decision overturning Proposition 8, Judge Walker relied heavily on the scientists' testimony and research, as his language clearly illustrates: "Sexual orientation is fundamental to a person's identity and is a distinguishing characteristic that defines gays and lesbians as a discrete group. Proponents' assertion that sexual orientation cannot be defined is contrary to the weight of the evidence"; "Material benefits, legal protections and social support, resulting from marriage can increase wealth and improve psychological well-being for married spouses"; and, "Standardized measures of relationship satisfaction, relationship adjustment and love do not differ depending on whether a couple is same-sex or opposite-sex" (Perry v. Schwarzenegger, 2010).

Clearly, social science research shaped policy related to marriage for same-sex couples, changing laws both in the U. S. and around the world. With these changes, researchers, sponsors of research, and policy makers must now consider the other side of the feedback loop, the influence of policy on science. How should the changed laws regarding marriage for same-sex couples influence the next wave of scholarship concerning these relationships? 


\section{Minority Stress in the Era of Marriage Equality}

Same-sex couples, after Obergefell v. Hodges (2015), can legally marry in any U. S. state. Previous marriages performed elsewhere are now legally recognized at the federal level. Same-sex couples now may secure the same legal rights, privileges, and recognition previously afforded only to mixed-sex couples.

In a "post-marriage" U. S., researchers can now investigate how access to equal marriage impacts the lived experiences and well-being of same-sex couples. Previous research was limited to the minority of U.S. states with legal same-sex marriage. Such research suggested that legal recognition for same-sex couples links to positive outcomes for mental health and well-being (Riggle et al., 2010; Wight et al., 2013), bolstering longstanding evidence of the health benefits of legal marriage for mixed-sex couples (Umberson et al., 2012). However, state-level marriage did not confer the same benefits and privileges as federal marriage, so more work is needed to better understand the impact of marriage access across the U. S. Large-scale, generalizable research can thrive, as more population-level datasets and public health surveillance systems include questions about sexual minority status. These new data can usefully combine with data routinely collected on marital status, now including same-sex couples.

The impact of equal marriage is likely not limited to same-sex couples, but generalizes to sexual minority individuals as well. As Hatzenbuehler (2014) and other scholars have noted, discriminatory marriage policies that exclude same-sex couples from the benefits, privileges, and recognition associated with legal marriage create structural stigma. Structural stigma negatively impacts all sexual minorities who live within a given social or geographical context, regardless of their relationship status. Indeed, before Obergefell v. Hodges (2015), sexual minority individuals (regardless of relationship status) living in states that prohibited same-sex marriage 
showed increases in mental health disorders from before to after the passage of such discriminatory restrictions (Hatzenbuehler et al., 2010). Sexual minorities living in states without discriminatory marriage policy showed no changes in rates of mental-health disorders across the same time, and heterosexuals across all states similarly showed no changes.

Despite structural stigma's demonstrably deleterious effects, changed marriage laws may not be enough to offset the social stigma that continues to create unequal relationship recognition for members of same-sex couples. As Meyer (2016) recently cautioned, equality under the law does not necessarily mean social equality: Just because revised marriage policy is nondiscriminatory does not mean other interpersonal forms of discrimination, prejudice, and stigma have been eliminated. Stigma, prejudice, and discrimination that sexual minorities experience as "minority stressors" can negatively impact health and well-being (Meyer, 2003) and can affect members of same-sex couples (see Rostosky \& Riggle, 2017a for a review). Furthermore, minority stress for same-sex couples is distinctive in that it is related to both their individual sexual minority identity and their relationship (LeBlanc et al., 2015). In support of Meyer's (2016) caution, same-sex couples experience couple-level minority stress more often in interpersonal contexts, particularly among families of origin, than in legal/policy contexts (Frost et al., 2017).

Needing to understand the interpersonal experience of policy change in a post-marriage context appears in same-sex couples' perceptions of recognition following the $2015 \mathrm{U}$. S. Supreme Court ruling (LeBlanc et al., 2018). Specifically, couples' perceptions that their relationships were unequally recognized by laws and society were predictive of poorer mental health, above and beyond whether or not members of same-sex couples were in a legally recognized relationship. By focusing on the degree to which couples perceive their relationships 
are treated equally by the laws and policies in society, this work demonstrates a need for researchers to look beyond indicators of structural stigma (i.e., legal marital status) in examining social determinants of sexual minority mental health and well-being. How much same-sex couples perceive their relationship to have unequal recognition is a meaningful factor underlying mental health outcomes above and beyond the legal status of their relationship (Kennedy \& Dalla, 2020). Although institutionalized discrimination, such as unequal access to legal marriage, has documented associations with mental health in sexual minority populations (Hatzenbuehler et al., 2010), the lived experience of perceived inequality likely represents a more proximal form of minority stress (Meyer, 2003), which can persist after eliminating structural stigma in the form of unequal marriage laws (LeBlanc et al., 2018). Future research on same-sex couples needs to address the complicated relationship between changing marriage policy and whether such structural changes translate to couples' own perceptions of the social value of their relationships, with implications for their lives in a post-marriage context.

\section{New Stressors}

In the move to marriage equality, social scientists and advocates for same-sex marriage often described the lack of access to marriage as a source of significant stressors in the lives of sexual minority individuals. As mentioned, research needs to address whether these stressors diminish subsequent to Obergefell v. Hodges (2015) and access to legal marriage at the federal level. Regardless, researchers also should attend to new and potentially unforeseen stressors resulting from marriage access.

First is the possibility of divorce and the relationship's legal dissolution. Data on divorce for same-sex couples in the U. S. is sparse, though likely forthcoming as researchers follow the trajectories of the first generation of couples to marry since the Obergefell decision. In 
Norwegian data collected over 18 years, starting in 1993 with their legalization of same-sex unions, couple-types differed in divorce rates (Wiik et al., 2014). Compared to mixed-sex couples, female same-sex couples were 2.28 times more likely to divorce and male same-sex couples were 1.38 times more likely to divorce. Additionally, female same-sex couples were 1.71 times more likely to divorce than male same-sex couples. In contrast, data from England and Wales comparing dissolution rates tell a different story (Ross et al., 2011). Specifically, mixed-sex marriages were more likely to end in divorce than same-sex civil partnerships were to end in dissolution; at the same time, female same-sex couples were more likely to dissolve their partnerships than were male same-sex couples. U. S. same-sex couples who are married or in other forms of legal commitments (e.g., civil unions) are no more likely (Rosenfeld, 2014) or perhaps less likely (Badgett \& Herman, 2013) to dissolve their legal partnerships than mixed-sex couples. With all these inconsistencies, both in findings and in the operational definition of marriage, additional data concerning divorce in same-sex couples are needed.

Also, same-sex and mixed-sex couples may experience divorce similarly and differently. Likely, divorce stresses same-sex couples in many of the same ways as mixed-sex couples. It involves a recognition of the end of a relationship that was, at least at some point, meaningful, and it requires the strenuous process of legally disentangling assets. At the same time, divorce potentially carries added stressors unique to same-sex couples. For example, given the recency of marriage equality, divorce for same-sex couples may not be well understood, both socially and legally. Writing about his own divorce in the Atlantic, Steven Petrow (2019) noted that many in his community seemingly minimized his divorce by referring to it as a "split" and failing to use the term "divorce" as they would have with a mixed-sex couple. Despite the marriage's end, 
Petrow felt that this degraded the actual marriage, writing: "I wanted the recognition afforded by the law to all divorcés, and respect—as measured by language — from our friends and family."

Legally, divorce for same-sex couples is also potentially puzzling. Although law may now disentangle marriage from gender, law may not do the same with regard to divorce (Kim \& Stein, 2018). Many same-sex couples' norms may clash with divorce law. For example, though many male same-sex couples are not sexually exclusive and have agreed-upon guidelines for this non-monogamy, courts may not recognize this. Consequently, courts may allow "adultery" to serve as a grounds for divorce, as has happened in mixed-sex marriages, and differentially apportion resources based on who was "at fault" (Kim \& Stein, 2018). Division of assets is another area where the norms of same-sex couples may clash with general assumptions in mixedsex couples. Divorce law tends to assume that couples share finances jointly and equally, an assumption that may not apply to some same-sex couples, who tend to show greater variety in sharing finances. Thus, “judges [may] deem greater proportions of income and property available to apportion between partners than they might have intended" (Kim \& Stein, 2018, p. 388).

In addition, divorce for same-sex couples may also serve as a stressor in potentially reflecting poorly on the larger lesbian, gay, bisexual, queer, and transgender (LGBTQ) community. In a New York Times opinion piece, Meredith Maran (2017) wrote: "Divorce felt like more than a betrayal of my wedding vows. It was a betrayal of my people and our cause." Particularly given stereotypes that same-sex couples are unstable and the use of such stereotypes in opponents' rhetoric against marriage for same-sex couples, divorce for same-sex couples can induce stereotype threat (Steele, 1997). Married sexual minority individuals may worry about confirming these stereotypes by ending the marriage or even by having a marriage that is not 
"picture-perfect." Researchers need to examine how such internalized pressures impact both divorce and marriage, and individual and relational well-being.

Another hypothesized stressor that needs empirical attention concerns the fragmenting of the LGBTQ community and the creation of hierarchies among couples, based on legal status and on assimilating to heteronormative models of relationships. Historically, sexual minority individuals and same-sex couples have existed outside the mainstream and as a result have been able to create their own norms around relationship formation and dissolution. Consequently, many seemingly equally valid models apply to being a same-sex couple. In the move to marriage for same-sex couples, which involved a very public fight that rhetorically placed marriage as the key issue facing the LGBTQ community and a key necessity for them, marriage may take over as a "gold-standard" for same-sex relationships. Subsequently, couples who do not seek marriage or who exist outside of heteronormative, monogamous relationships may experience a reduced status within the community, further marginalizing them (Knauer, 2018). Additionally, marriage for same-sex couples may create schisms between the LGBTQ community and progressive feminists, many who have argued for a move away from marriage as an institution they claim is fundamentally patriarchal, heteronormative, and narrow (Diamond, 2017). Finally, to the extent that marriage provides access to status, many same-sex couples may seek to marry, despite not being ready or the option being the best one, as a way to gain resources and, perhaps more importantly, approval from those around them (Knauer, 2018).

\section{Emerging Adults}

Another avenue concerns research across a wider part of the life course. Most scholarship on same-sex couples and same-sex marriage has focused on adults-given the people in samesex couples for whom marriage is a possibility are adults. However, the changes in the social 
climate that parallel or result from changes in marriage policy are likely to have a significant impact on the lives and relationships of new generations of individuals who come of age in a post-marriage social and policy context. Thus, many unanswered questions pertain to the impact of changes in marriage policy for the current cohorts of sexual minority adolescents and emerging adults (Frost et al., 2015).

Romantic and sexual desire, along with an increasing interest in romantic relationships and dating, have long been understood to be key concerns in the lives of adolescents and emerging adults in general (Arnett, 2000), as well as for sexual minority youth specifically (Frost et al., 2015). Historically, the possibilities of dating and forming relationships have been more restricted, and sometimes even impossible, for sexual minority adolescents and emerging adults due to the policies criminalizing same-sex sexual behavior (before 2003) and prevailing negative attitudes toward homosexuality in the U. S. (Meyer \& Dean, 1998). However, over the past two decades, leading up to Obergefell v. Hodges (2015), attitudes toward same-sex marriage and homosexuality in general improved, especially among younger generations (Pew, 2019).

Changed attitudes toward same-sex sexuality and relationships among younger U.S. generations have led some to argue that newer cohorts of sexual minority individuals are coming of age in a "post gay" era (e.g., Savin-Williams, 2005) and that sexual minority adolescents and emerging adults are not as marginalized and stigmatized as previous generations of sexual minorities. This is perhaps a controversial proposition given that sexual minority adolescents and emerging adults continue to face disproportionally high rates of victimization, harassment, and negative health outcomes relative to their heterosexual peers (for a review, see Russell \& Fish, 2016). Nevertheless, given the drastically improved social and policy climate, current cohorts of sexual minority young people are socialized in a radically different environment than any 
previous generation. Consistently, the current cohort of sexual minority youth are coming out (i.e., disclosing their sexual orientation to important others) at increasingly younger ages (Floyd \& Bakeman, 2006). Additionally, greater proportions of the population of adolescents and emerging adults are identifying as sexual minorities than in previous cohorts (Newport, 2017).

Scholars have rightfully highlighted a potential "developmental collision" for new generations of sexual minorities (Russell \& Fish, 2019), evident in the juxtaposition of the postmarriage climate and the emergence of a more visibly out generation of sexual minority adolescents and emerging adults within a continued climate of stigma and minority stress (Meyer, 2016). Many questions relate to how adolescents and emerging adults pursue and experience relationships in a post-marriage context. For example, has the changing sociopolitical climate impacted the formation and maintenance of same-sex relationships in adolescence and emerging adulthood? If a more accepting social climate diminishes interpersonal and intrapersonal barriers to relationship formation for sexual minority adolescents and emerging adults, then same-sex and heterosexual relationship formation may now be occurring at the same rate and during the same developmental period (Collins et al., 2009). Romantic relationships may initiate earlier in sexual minority identity development and shape sexual minority identity more than is currently understood. Sexual minorities and heterosexuals may or may not differ in relational concerns and aspirations for marriage and children across adolescence and emerging adulthood, now that the current generation is growing up in a society where legal marriage is a possibility.

\section{Implications for Mixed-sex Couples}

Marriage for same-sex couples may impact the marriages of mixed-sex couples and the institution of marriage more generally. In the path to marriage equality, many opponents 
suggested that granting same-sex couples access to marriage would fundamentally change the meaning of marriage and would undermine what marriage means to mixed-sex couples (Badgett, 2004). As a result, they worried that the health and stability of marriage for mixed-sex couples would be jeopardized. For example, when social psychologist Anne Peplau testified in Perry $v$. Schwarzenegger (2010), the federal case examining California's Proposition 8, she was asked whether marriage for same-sex couples would decrease mixed-sex couples entering marriage while simultaneously increasing these couples getting divorced. Citing data on marriage rates in Massachusetts subsequent to that state granting marriage to same-sex couples, Peplau suggested no. (She also famously stated that she could not imagine that in the wake of same-sex marriage, a husband would turn to his wife and say, "Gertrude, we've been married for 30 years, but I think we have to throw in the towel because Adam and Stewart down the block got married" (Transcripts Volume 3, 2010, pp. 601-602), a statement that the first author of this article prizes as he is Adam and his husband is Stewart). Of course, the link between marriage equality and rates of marriage and divorce will need study over time, to investigate any potential longer-term consequences of a change in marriage policies.

Beyond rates of initiation and dissolution, researchers should also investigate other impacts of same-sex marriage more broadly, for example the meaning of gender and gender roles in marriage. Both legally and socially, marriage has centered on a strict division based on gender and on a hierarchy that grants husbands power over wives (Peplau \& Fingerhut, 2007). Marriages where both partners are of the same gender necessarily challenge this. One simply has to consider the deeply embedded unidirectional practice of men proposing marriage to women to see the ways in which patriarchy is ingrained in heterosexual marriage and the ways that this cannot work for same-sex couples. As a result, same-sex couples offer creative new ways to 
think about marriage. For example, in his 2004 wedding, the first author and his husband created two aisles and processed down simultaneously as a sign of the egalitarian nature of their relationship.

Marriage for same-sex couples arguably may disrupt the traditional gender roles that seem inextricably linked with marriage (Hunter, 1991; 2012). Of course, gendered scripts in mixed-sex marriages have already been changing, largely due to the dramatic shifts in women's labor-force participation. Still, the presence of same-sex marriages might further disrupt gender norms. For example, differences in division of labor between same- and mixed-sex couples may inform a new norm in all marriages (Hunter, 2012). Though division of labor inequality exists in both couple types and a move to more equal division of labor has occurred in mixed-sex couples in the recent past, generally same-sex couples divide household labor more equally than do mixed-sex couples (Fingerhut \& Peplau, 2012; Solomon et al., 2005). Additionally, due to the gender homogeneity in same-sex couples, division of labor cannot be based on each partner's gender and must be based on other factors such as interest or specialization. The existence of same-sex marriage, and with it the fuller inclusion of same-sex couples in society, may make more salient to heterosexuals both the unequal division and gendered nature of household labor as well as possible alternatives to the status quo. Thus while the Gertrude mentioned in Anne Peplau's quote above may not seek to end her marriage now that two men or two women can marry, she may ask that the household chores happen differently.

Other characteristics of same-sex couples as distinct from mixed-sex couples may also become more widely adopted. In one review, a positive-psychology framework identified various strengths in same-sex couples (Rostosky \& Riggle, 2017b), including appreciating differences, communicating effectively, having egalitarian ideals, and developing emotional 
intimacy. Because many of the included studies sampled only same-sex couples, these strengths may or may not distinguish same-sex couples from their counterparts. Future research needs to clarify this. Still, some between-group comparisons did show distinctions. During a discussion involving a relationship conflict (Gottman et al., 2003), same-sex couples used more positive emotions, including humor, affection, and joy, than negative emotions, in comparison to mixedsex couples. Indeed: "When it comes to emotions, we think [same-sex] couples may operate with very different principles than straight couples. Straight couples may have a lot to learn from gay and lesbian relationships." (The Gottman Institute, n.d.). Notably, male same-sex couples and female same-sex couples are not interchangeable in comparison to mixed-sex couples, and each may offer strengths the other does not. For example, female same-sex couples may utilize more positivity in problem solving (Kurdek, 2001) and achieve more harmony during conflict (Roisman et al., 2008) than either male same-sex or mixed-sex couples (Rostosky \& Riggle, 2017b).

As possible as mixed-sex couples borrowing from same-sex couples and changing marriage, perhaps just as plausibly, same-sex couples who choose to marry, and perhaps samesex couples more broadly, may assimilate to the patterns of mixed-sex couples. Perhaps this best appears in the data concerning same-sex couples rearing children. In the 2014-2016 American Community Survey, more married same-sex couples were raising children than were unmarried same-sex couples (21.9\% vs. 12.2\%; Goldberg \& Conron, 2018). Furthermore, of the same-sex couples raising children, those who were married were more likely to have adopted children than those who were not married $(24.7 \%$ vs. $17.1 \%)$. This becomes relevant when one considers the myriad ways in which sexual minority individuals become parents. Even today, sexual minority individuals who are parenting largely entered that role in the context of a previous heterosexual 
relationship, often before they came out and identified as sexual minorities (Goldberg \& Gartrell, 2014). However, for many who adopt, they do so in the context of an already existing same-sex relationship. In other words, the relationship preceded the child and may have informed the choice to have a child. Thus, this difference in adoption between married versus not married same-sex couples could reflect that marriage, even marriage for same-sex couples, maintains its strong link to child-rearing.

\section{Concluding Remarks}

Our purpose has been twofold. First, we hope to shed light on possible future directions for research with regard to same-sex couples (and mixed-sex couples) in a new era of marriage equality. While researchers and research sponsors interested in sexual minority populations should be interested in the ideas presented here, others should attend to the suggestions as well. For example, those who study couples and marriage more broadly benefit from an opportunity to generalize mainstream theories and findings in a new era of marriage. Additionally, those interested in structural stigma have a case study to examine the impacts of a radical shift in policy on constructs such as health and perceived stigma among a marginalized group as well as changes in attitudes and discriminatory behaviors among those in the majority. Policy makers should also pay attention to the suggested research as a means to assess the effectiveness of the policies they have created.

Second, and perhaps at a broader level, we highlight the feedback loop between science and policy. Scientists often focus on how science informs policy. Perhaps under recognized are the ways that policy should influence future research agendas. Ultimately, an ongoing feedback loop must exist between psychological science and policy such that policy makers create policies 
grounded in data, researchers empirically assess the effectiveness (or lack thereof) of the policies, and the data then inform the subsequent work of the policy makers.

The paper focuses perhaps narrowly on the science and policy link present in the marriage equality movement in the U. S. and other westernized countries; importantly, however, the critical role of this link extends to other places, issues, and populations. Many locations across the globe marginalize and criminalize sexual minority individuals and have not witnessed the same gains as in the U. S. and Europe (Meyer, 2016). Thus, larger global conversations and coordination with global human rights organizations, such as the United Nations' Free and Equal program, need data to make the case for LGBTQ equal rights everywhere. As well, U. S. lawmakers and courts need data to deal with new waves of questions and policies that directly and/or indirectly target the LGBTQ community. Illustrative of these are myriad court cases in which free exercise of religion and equal protection clauses are essentially being pitted against one another. To date, the most high profile of these cases was Masterpiece Cakeshop v. Colorado Civil Rights Commission (2018), in which a Colorado cakeshop owner refused to make a cake for a same-sex wedding based on religious objections. The shop owner eventually won the case; however, the issue of religious objections versus anti-discrimination laws was not answered and remains a contentious issue facing law and policy makers, one for which social science data have much to say. Finally, though this paper focuses on scholarship and policies related to sexual minority populations, the symbiotic relationship between science and policy applies broadly and should be modeled in addressing inequality related to other populations, including issues relevant to immigrant populations and to People of Color.

Ultimately, the recent advances in rights for same-sex couples have made more salient than ever the bidirectional link between psychological science and policy. Moving forward, 
scientists and policy makers need to attend to this reality further, both for the advancement of science in the public's interest and for the creation of just policies grounded in data. 


\section{References}

Arnett, J. J. (2000). Emerging adulthood: A theory of development from the late teens through the twenties. American Psychologist, 55(5), 469-480. https://doi.org/10.1037/0003066X.55.5.469

Badgett, M. V. L. (2004). Will providing marriage rights to same-sex couples undermine heterosexual marriage? Sexuality Research and Social Policy, 1, 1-10. doi:10.1525/srsp.2004.1.3.1.

Badgett, M. V. L., \& Herman, J. L. (2013). Patterns of relationship recognition by same-sex couples in the United States. In A. K. Baumle (Ed.), International handbook on the demography of sexuality (Volume 5). Springer, Dordrecht. https://doi.org/10.1007/978$94-007-5512-3$

Collins, W. A., Welsh, D. P., \& Furman, W. (2009). Adolescent romantic relationships. Annual Review of Psychology, 60, 631-652.

Diamond, L. M. (2017). Three critical questions for future research on lesbian relationships. Journal of Lesbian Studies, 21, 106-119. doi: 10.1080/10894160.2016.1143756

Fingerhut, A.W., \& Peplau, L. A. (2013). Same-sex romantic relationships. In C. J. Patterson \& A. R. D’Augelli (Eds.), Handbook of psychology and sexual orientation (pp. 165-178). New York: Oxford University Press.

Floyd, F. J., \& Bakeman, R. (2006). Coming-out across the life course: Implications of age and historical context. Archives of Sexual Behavior, 35, 287-296.

Frost, D. M., LeBlanc, A. J., de Vries, B., Alston-Stepnitz, E., Stephenson, R., \& Woodyatt, C. (2017). Couple-level minority stress: An examination of same-sex couples' unique experiences. Journal of Health and Social Behavior, 58(4), 455-472. 
Frost, D. M., Meyer, I. H., \& Hammack, P. L. (2015). Health and well-being in emerging adults' same-sex relationships: Critical questions and directions for research in developmental science. Emerging Adulthood, 3(1), 3-13.

Goldberg, A. E., \& Gartrell, N. K. (2014). LGB-parent families: The current state of the research and directions for the future. Advances in Child Development and Behavior, 46, 57-88. 10.1016/B978-0-12-800285-8.00003-0.

Goldberg, S. K., \& Conron, K. J. (2018). How many same-sex couples in the U.S. are raising children? Los Angeles, CA: The Williams Institute.

Gottman, J. M., Levenson, R. W., Swanson, C., Swanson, K., Tyson, R., \& Yoshimoto, D. (2003). Observing gay, lesbian and heterosexual couples' relationships: mathematical modeling of conflict interaction. Journal of Homosexuality, 45, 65-91.

The Gottman Institute (n.d.). Same-sex couples. https://www.gottman.com/about/research/samesex-couples/

Hatzenbuehler, M. L. (2014). Structural stigma and the health of lesbian, gay, and bisexual populations. Current Directions in Psychological Science, 23(2), 127-132.

Hatzenbuehler, M. L., McLaughlin, K. A., Keyes, K. M., \& Hasin, D. S. (2010). The impact of institutional discrimination on psychiatric disorders in lesbian, gay, and bisexual populations: A prospective study. American Journal of Public Health, 100(3), 452-459.

Heise, J. (2005). Brown v. Board of Education, footnote 11, and multidisciplinarity. Cornell Law Review, 90, 279-320. http://scholarship.law.cornell.edu/clr/vol90/iss2/1

Hunter, N. D. (1991). Marriage, law, and gender: A feminist inquiry. Law \& Sexuality: Review of Lesbian and Gay Legal Issues, 9. 
Hunter, N. D. (2012). The future impact of same-sex marriage: More questions than answers. The Georgetown Law Journal, 100, 1855-1879. https://scholarship.law.georgetown.edu/facpub/1089

In re Marriage cases, 43 Cal.4th 757 (Cal. 2008)

Kennedy, H. R., \& Dalla, R. L. (2020). "It may be legal, but it is not treated equally": marriage equality and well-being implications for same-sex couples. Journal of Gay \& Lesbian Social Services, 32(1), 67-98.

Kim, S. A. \& Stein, E. (2018). Gender in the context of same-sex divorce and relationship dissolution. Family Court Review, 56, 384-398. doi:10.1111/fcre.12355

Knauer, N. J. (2018). Implications of Obergefell for same-sex marriage, divorce, and parental rights. In A. E. Goldberg \& A. P. Romero (Eds.), LGBTQ divorce and relationship dissolution: Psychological and legal perspectives and implications for practice. doi: 10.1093/med-psych/9780190635176.003.0002

Kurdek, L. A. (2001). Differences between heterosexual-nonparent couples and gay, lesbian, and heterosexual-parent couples. Journal of Family Issues, 22, 727-754. http://dx.doi.org/10.1177/019251301022006004

LeBlanc, A. J., Frost, D. M., \& Bowen, K. (2018). Legal marriage, unequal recognition, and mental health among same-sex couples. Journal of Marriage and Family, 80(2), 397-408.

LeBlanc, A. J., Frost, D. M., \& Wight, R. G. (2015). Minority stress and stress proliferation among same-sex and other marginalized couples. Journal of Marriage and Family, 77(1), 40-59. 
Maran, M. (2017, January 7). I got gay married. I got gay divorced. I regret both. The New York Times. https://www.nytimes.com/2017/01/07/opinion/sunday/i-got-gay-married-i-gotgay-divorced-i-regret-both.html

Masterpiece Cakeshop v. Colorado Civil Rights Commission, 84 U.S. __ (2018).

Meyer, I. H. (2003). Prejudice, social stress, and mental health in lesbian, gay, and bisexual populations: conceptual issues and research evidence. Psychological Bulletin, 129(5), 674.

Meyer, I. H. (2016). The Elusive Promise of LGBT Equality. American Journal of Public Health, 106(8), 1356.

Meyer, I.H., \& Dean, L. (1998). Internalized homophobia, intimacy, and sexual behavior among gay and bisexual men. In G. M. Herek (Ed.) Stigma and sexual orientation: Understanding prejudice against lesbians, gay men, and bisexuals (pp. 160-186). Thousand Oaks, CA: Sage Publications.

Newport, F. (2017). Gallup News: In U.S., Estimate of LGBT Population Rises to 4.5\%. Accessed on May 26, 2020 at: https://news.gallup.com/poll/234863/estimate-lgbtpopulation-rises.aspx

Obergefell v. Hodges. 576 U. S. (2015).

Peplau, L. A., \& Fingerhut, A. W. (2007). The close relationships of lesbians and gay men. Annual Review of Psychology, 58, 405-424.

doi:10.1146/annurev.psych.58.110405.085701

Perry v. Schwarzenegger, 704 F. Supp. 2d 921 (N.D. Cal. 2010)

Petrow, S. (2019, June 20). Celebrating my (gay) divorce. The Atlantic. https://www.theatlantic.com/family/archive/2019/06/gay-marriage-gay-divorce/592006/ 
Pew Research Center (2019, May). Fact Sheet: Attitudes on Same-Sex Marriage. Accessed on 5/6/2020 at: https://www.pewforum.org/fact-sheet/changing-attitudes-on-gay-marriage/.

Riggle, E. D., Rostosky, S. S., \& Horne, S. G. (2010). Psychological distress, well-being, and legal recognition in same-sex couple relationships. Journal of Family Psychology, 24(1), 82.

Roisman, G. I., Clausell, E., Holland, A., Fortuna, K., \& Elieff, C. (2008). Adult romantic relationships as contexts of human development: A multimethod comparison of same-sex couples with opposite-sex dating, engaged, and married dyads. Developmental Psychology, 44, 91-101. http://dx.doi.org/10.1037/0012-1649.44.1.91

Rosenfeld, M. J. (2014) Couple longevity in the era of same-sex marriage in the U.S. Journal of Marriage and Family, 76, 905-918.

Ross, H. K., Gask, K., \& Berrington, A. M. (2011). Civil partnerships five years on. Population Trends, $145,172-202$.

Rostosky, S. S., \& Riggle, E. D. B. (2017a). Same-sex relationships and minority stress. Current Opinion in Psychology, 13, 29-38.

Rostosky, S. S., \& Riggle, E. D. B. (2017b). Same-sex couple relationship strengths: A review and synthesis of the empirical literature (2000-2016). Psychology of Sexual Orientation and Gender Diversity, 4(1), 1-13. https://doi.org/10.1037/sgd0000216

Russell, S. T., \& Fish, J. N. (2016). Mental health in lesbian, gay, bisexual, and transgender (LGBT) youth. Annual Review of Clinical Psychology, 12, 465-487.

Russell, S. T., \& Fish, J. N. (2019). Sexual minority youth, social change, and health: A developmental collision. Research in Human Development, 16(1), 5-20. 
Savin-Williams, R. C. (2005). The new gay teenager. Cambridge, MA: Harvard University Press.

Solomon, S. E., Rothblum, E. D., \& Balsam, K. F. (2005). Money, housework, sex, and conflict: Same-sex couples in civil unions, those not in civil unions, and heterosexual married siblings. Sex Roles, 52(9-10), 561-575. https://doi.org/10.1007/s11199-005-3725-7

Steele, C. M. (1997). A threat in the air: How stereotypes shape intellectual identity and performance. American Psychologist, 52(6), 613-629. https://doi.org/10.1037/0003066X.52.6.613

Transcripts Volume 3. (2010, January 13). Perry et al. v. Schwarzenegger. California: United States District Court Northern District of California.

Umberson, D., Thomeer, M. B., \& Williams, K. (2013). Family status and mental health: Recent advances and future directions. In Handbook of the sociology of mental health (pp. 405431). Springer, Dordrecht.

Wight, R. G., LeBlanc, A. J., \& Badgett, M. V. L. (2013). Same-sex legal marriage and psychological well-being: findings from the California Health Interview Survey. American Journal of Public Health, 103(2), 339-346.

Wiik, K. A., Seierstad, A. \& Noack, T. (2014). Divorce in Norwegian same-sex marriages and registered partnerships: The role of children. Journal of Marriage and Family, 76, 919929. doi:10.1111/jomf.12132

Yep, G. A., Lovaas, K. E., \& Elia, J. P. (2003). A critical appraisal of assimilationist and radical ideologies underlying same-sex marriage in LGBT communities in the United States. Journal of Homosexuality, 45(1), 45-64. 